\title{
Assessment of climate change impacts on water resources of the Purus Basin in the southwestern Amazon
}

\author{
Ricardo DALAGNOL ${ }^{1 *}$, Laura de Simone BORMA², Pedro MATEUS ${ }^{3}$, Daniel Andres RODRIGUEZ ${ }^{2}$ \\ 1 Remote Sensing Division (DSR), National Institute for Space Research (INPE), São José dos Campos-SP, 12227-010, Brazil, email: ricardo.silva@inpe.br \\ 2 Earth System Science Center (CCST), National Institute for Space Research (INPE), São José dos Campos-SP, 12227-010, Brazil \\ ${ }^{3}$ Dom Luiz Institute (IDL), University of Lisbon, Portugal \\ * Corresponding author: ricardo.silva@inpe.br
}

\section{ABSTRACT}

Knowledge about water resources is critical for climate adaptation in face of long-term changes and more frequent extreme events occurrence. During the major droughts of 2005 and 2010, a large epicenter was located in the southwestern Amazon over the Purus River Basin. In this sense, we conducted a hydrological simulation in this basin to assess the climate change impacts on its water resources throughout the 21 st century. The water balance was simulated using the Distributed Hydrological Model (MHD-INPE). The future climate projections were simulated by the regional ETA-INPE model driven by a 4-member HadCM3 global model regarding the A1B-AR4/IPCC scenario of greenhouse gases emissions. As simulated by the ETA-INPE/ HadCM3, the 4-members mean response for the A1B scenario represents a rainfall reduction of up to $11.1 \%$, a temperature increase of up to $4.4{ }^{\circ} \mathrm{C}$, and a wind speed increase of up to $8.4 \%$ in the Purus Basin by the end of 21 st century. Under these conditions, the discharge projections represent an overall $27 \%$ decrease in the Purus Basin with different patterns between dry and wet season, as well as changes in seasonality trends. The consequences of projected climate change are severe and will probably have a great impact upon natural ecosystem maintenance and human subsistence. In a climate change adaptation process, the preservation of the natural forest cover of the Purus Basin may have great importance in water retention.

KEYWORDS: climate change, hydrologic modeling, adaptation

\section{Avaliação de impactos de mudanças climáticas nos recursos hídricos da Bacia do Purus no sudoeste da Amazônia}

\section{RESUMO}

O conhecimento sobre os recursos hídricos é crítico para a adaptação diante das mudanças de longo prazo e ocorrência mais frequente de eventos extremos. Nas grandes secas de 2005 e 2010, um grande epicentro foi localizado no sudoeste da Amazônia sobre a Bacia do Rio Purus. Nesse sentido, foi realizada uma simulação hidrológica nessa bacia, para avaliar os impactos das mudanças climáticas sobre seus recursos hídricos ao longo do século 21. O balanço hídrico foi simulado utilizando o modelo hidrológico distribuído (MHD-INPE). As projeçóes climáticas futuras foram simuladas pelo modelo regional ETA-INPE forçado por 4 membros do modelo global HadCM3 sobre o cenário de emissóes de gases de efeito estufa A1B-AR4/IPCC. Como simulado pelo ETA-INPE/HadCM3, a resposta média dos 4 membros para o cenário A1B representa uma redução de chuvas em até $11,1 \%$, aumento de temperatura em até $4,4^{\circ} \mathrm{C}$, e aumento da velocidade do vento em até $8,4 \%$ para a Bacia do Purus até o fim do século 21. Sob essas condições, as projeçóes de descarga representam uma diminuição global de $27 \%$ na Bacia do Purus, com diferentes padróes entre as estaçôes seca e úmida, bem como mudanças nas tendências sazonais. As consequências das mudanças climáticas projetadas são severas e provavelmente teráo um grande impacto sobre a manutenção dos ecossistemas naturais e subsistência humana. Em um processo de adaptação a mudanças climáticas, a preservação da cobertura florestal natural da Bacia do Purus pode ter grande importância na retenção de água.

PALAVRAS-CHAVE: mudanças climáticas, modelagem hidrológica, adaptação 


\section{INTRODUCTION}

With an area of 7.5 million $\mathrm{km}^{2}$ and an average annual rainfall of $2000 \mathrm{~mm}_{\text {year }}{ }^{-1}$, the Amazon Basin is the largest hydrographic basin on the planet and recognized worldwide not only by the abundant tropical rainforest and environmental services it provides but also by its water abundance. Due to the combination of rainfall and relief to the ocean, one of the most extensive floodplains on the planet $\left(800,000 \mathrm{~km}^{2}\right)$ occurs in the Amazon (Melack et al. 2009; Melack and Hess 2010). Thousands of rural river dwellers live on the floodplains, in the seasonally flooded and terra-firme areas, managing, producing and extracting resources for local, regional, national and global consumption and marketing since pre-Columbian times (Costa and Brondízio 2011).

Although drought and flood episodes are part of the climate pattern of the Amazon, extreme events that occurred in the last decades put the scientific community on alert (Borma and Nobre 2013). Most models presented in the 4th Assessment Report of the Intergovernmental Panel on Climate Change (AR4/IPCC) simulate a drier and warmer climate for the Amazon. The A1B-AR4/IPCC scenario projected that greenhouse gasses (GHG) emissions would rise from 40 to 80 $\mathrm{Gt} \mathrm{CO}$ eq $\mathrm{yr}^{-1}$ until the first half of 21 st century, then decline to $60 \mathrm{Gt} \mathrm{CO}_{2}$ eq $\mathrm{yr}^{-1}$ until the end of it (Solomon et al. 2007).

Despite the uncertainties in climate model predictions, global climate change may exacerbate the effects of local impacts, causing changes in water and energy cycles in a near future. As a result, several studies were carried out to evaluate the impacts of these events on natural and human systems. While extremes of drought seem to be more deleterious to terra-firme forests (Phillips et al. 2009), flood episodes have been shown to be more impacting to the varzea environments and riparian communities (Pinho et al. 2012; Borma et al. 2013; Piedade et al. 2013; Osuna et al. 2014).

During the major droughts of 2005 and 2010, a large epicenter was located in the southwestern part of the Amazon Basin, over the Purus River Basin (Lewis et al. 2011). This basin has an extent of $376,000 \mathrm{~km}^{2}$ and is one of the main watersheds of the right margin of the Solimóes-Amazonas River. Unlike other Amazonian basins, the Purus hydrological behavior probably has not been strongly modified by land use and cover change (LUCC), since only $5.4 \%$ of its area is deforested (Trancoso et al. 2009). Hence, discharge variations should be more related to climate variability than to the impacts of LUCC.

The aim of this study was to evaluate the climate change impacts on the hydrological regime of the Purus Basin in the southwestern Amazon throughout the 21st century regarding the A1B-AR4/IPCC scenario. We aimed at estimating the magnitude of the climate change impacts on the discharge of the Purus River and its major tributaries.

\section{MATERIALS AND METHODS}

\section{Study area}

The study area is the Purus Basin, which is mostly located in the southwestern Amazon depression, with elevations from 50 to $500 \mathrm{~m}$. It comprehends areas from Brazil, Peru, and Bolivia (Figure 1). The Purus River is born in Peru at $500 \mathrm{~m}$ elevation, flows into the Solimóes River and drains an area of approximately $376,000 \mathrm{~km}^{2}$.

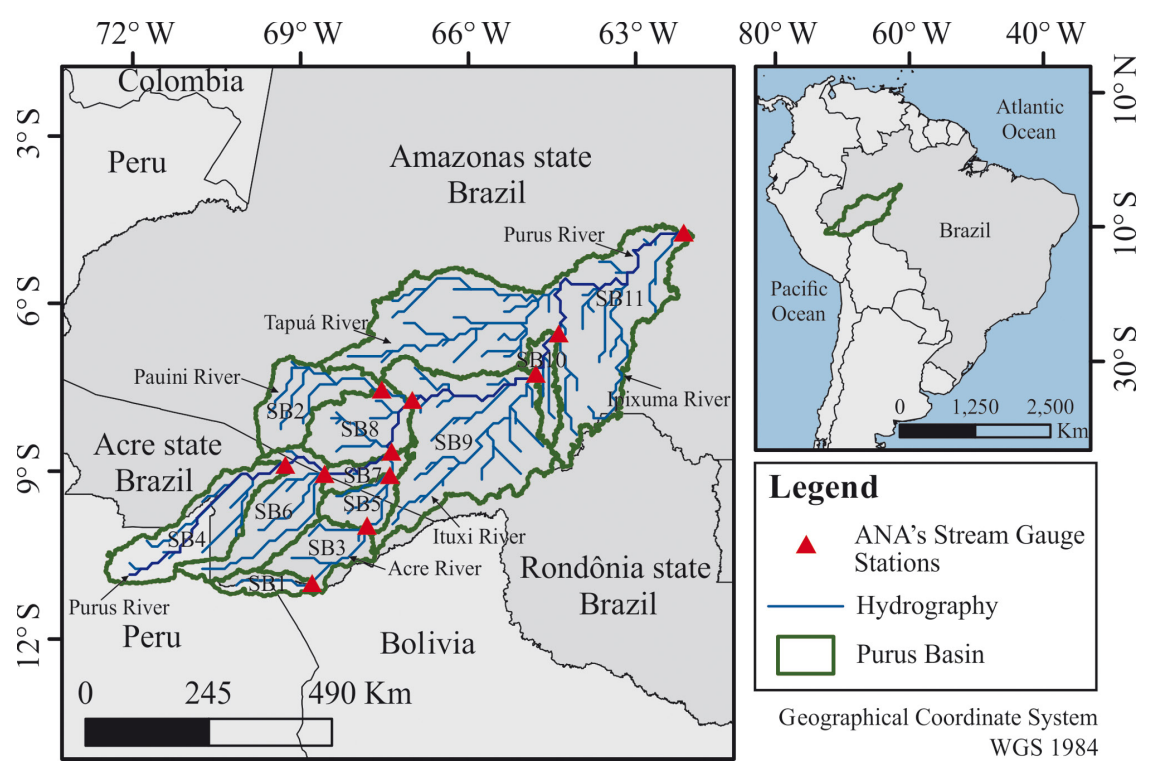

Figure 1. Location of the Purus River Basin in the southwestern Amazon. This figure is in color in the electronic version. 
Native vegetation is composed mostly of lowland and alluvial dense ombrophylous forest, open ombrophylous forest, and small patches of savannah Cerrado (IBGE 1992). Some ecological tension areas with mixed vegetation cover occur near Rio Branco, the capital of the state of Acre. The Purus Basin is one of the most preserved basins in Amazonia, with only about $5.4 \%$ deforested area (Trancoso et al. 2009). The basin's eastern region is an agricultural frontier, near the BR-364, BR-319 and BR-230 highways, which poses a threat to the basin's native vegetation (Reid et al. 2005; Sousa Júnior et al. 2006).

The region's climate is classified as Köppen Af (humid equatorial). This climate is found along the equator and is characterized by a minimum monthly rainfall of $60 \mathrm{~mm}$ and average temperature ranging from 26 to $28^{\circ} \mathrm{C}$ (Peel $e t$ al. 2007). Two seasons are defined by rainfall in the Purus Basin: a dry season from April to September, and a wet season from October to March. Rainfall peaks from December to February, and is lowest from May to August, with monthly averages of 300 and $60 \mathrm{~mm}$, respectively. The high river level and discharge season ranges from January to June, with a mean discharge of $12,000 \mathrm{~m}^{3} \mathrm{~s}^{-1}$. The low river level season ranges from July to December, with a mean discharge of $1,500 \mathrm{~m}^{3} \mathrm{~s}^{-1}$. The annual average river discharge is $8,500 \mathrm{~m}^{3}$ $\mathrm{s}^{-1}$ (Hamski 2006).

The Purus River carries an abundant load of suspended sediments coming from the Andes (McClain and Naiman 2008). The erosion caused by these sediments leads to a continuous process of changing courses, resulting in an asymmetrical pattern of meandering courses. The river is very rich in nutrients, and for this reason, it is also rich in aquatic species (McClain and Naiman 2008). Hence, approximately 13,000 people live along the Purus River, pursuing subsistence activities, such as fishing, farming, and wood extraction (FUNASA 2006). This population is composed of settlers, smallholders, and indigenous people, concentrated mainly along the main channel of the Purus River, in small cities, indigenous reserves, and rural settlements (Sousa Júnior et al. 2006).

\section{Observational data}

We used a climate and environmental dataset for 19701990 composed of a digital elevation model (DEM), land cover and land use maps, vegetation physiognomy map and its hydrological parameters, soil map, and its physical parameters, meteorological and river discharge data. Due to the large extent of the basin and the heavy computational costs of modeling the data was resampled to a regular grid with 10 $\mathrm{km}$ horizontal spatial resolution.

The DEM data was obtained from Shuttle Radar Topography Mission (SRTM) $90 \mathrm{~m}$ horizontal resolution elevation data (USGS 2004). The SRTM data was processed in TerraView 4.2.2 Hidro 0.3.8 software (INPE 2016) in order to generate topographic parameters of slope, delineation of sub-basins (SB), contributing area of each SB, and deriving topographic indexes related to the water flow pathways on the relief (Seibert and McGlynn 2007).

Annual composition of land cover and land use maps were obtained from Leite et al. (2011). Vegetation physiognomy maps were obtained from PROVEG/IBGE (Vieira et al. 2013). The maps presented $1 \mathrm{~km}$ original resolution and land cover classes followed the Simplified Simple Biosphere Model (SSiB) (Xue et al. 1991). A mean climatology of hydrological vegetation parameter data was obtained for each physiognomy from the literature: albedo, leaf area index, average tree height, canopy cover, root depth, zero displacement plan, canopy roughness, surface resistance, maximum canopy capacity, critical omega and roots distribution factor (Dorman and Sellers 1989; Culf et al. 1996; Ubarana 1996; Nepstad et al. 2004; LDAS-NASA 2014). The soil map had $10 \mathrm{~km}$ resolution and 16 texture classes and its physical parameters were derived from pedotransference functions (Doyle et al. 2013).

Atmospheric pressure, solar radiation, dew point temperature, air temperature, wind speed, and rainfall were observed by 10 meteorological weather stations belonging to several local and national institutes, as well as 7 additional rainfall stations belonging to the Brazilian National Water Agency (ANA) (Mateus et al. 2016). The meteorological and rainfall data were interpolated to regular $10-\mathrm{km}$ horizontal resolution grids for the basin extent using inverse distance weight method (Shepard 1968).

River discharge and/or water level data were obtained from 11 stream gauge stations managed by ANA inside the Purus Basin (ANA 2016). Whenever the discharge data was missing, but water level data was available, a rating curve adjustment approach was applied to convert between the two variables. These data were used to calculate parameters regarding the basin and river drainage: mean discharge per $S B$, mean specific discharge, delay parameter of the underground reservoir per SB, and river width estimates (Rodriguez 2011).

\section{Climate model projections}

The climate projections were simulated using the ETAINPE regional climate model (RCM) nested with four members of an ensemble of the UK Met Office Hadley Centre HadCM3 global climate model (GCM) (Chou et al. 2012). The members were generated by introducing perturbations to the GCM physical parameterization schemes in order to account for the uncertainty of the boundary conditions. They were chosen considering its sensitivity to the global mean temperature response: one unperturbed member, the control (M1); and three perturbed members, low (M2), medium 
(M3) and high (M4). The A1B-AR4/IPCC scenario was used to force the model and simulate climate projections for the 21st century (Solomon et al. 2007). The resulting modeled meteorological variables (same as observational data) constituted the ETA future climate projections dataset, which was divided into four time periods: historical (1970-1990); and three projections (2011-2040, 2041-2070 and 20712099). The original ETA spatial resolution corresponded to $40 \mathrm{~km}$ horizontal resolution and 38 vertical layers. To match the local-scale used in the MHD-INPE hydrological model, a downscaling method was applied to the ETA data.

Since GCM outputs cannot be used to force hydrological models without prior bias correction (Feddersen and Andersen 2005), adjustments were applied on the meteorological data. The historical dataset response was adjusted to match the observed dataset, and the coefficients used for this correction were applied to adjust the mean response of projection datasets, following the assumption that the bias between ETA and observed data would be the same for present and future time periods. Rainfall data was adjusted using the statistical percentile-percentile method (Bárdossy and Pegram 2011), while the rest of the variables were adjusted using the linear scaling method (Lenderink et al. 2007; Teutschbein and Seibert 2013). The performance of adjustments was assessed using the coefficient of determination $\left(\mathrm{R}^{2}\right)$, plots of the adjusted variables climatologies and descriptive statistics.

\section{MHD-INPE hydrological model}

The Distributed Hydrological Model developed by the Brazilian National Institute for Space Research (MHDINPE) is a large-scale, top-down, distributed and processbased hydrological model that integrates water and energy balances in order to simulate river discharges of large basins (Rodriguez 2011; Rodriguez and Tomasella 2015). MHDINPE has been validated and applied over Amazon sub-basins in several studies (Von Randow et al. 2012; Mohor et al. 2015; Rodriguez and Tomasella 2015).

The model was initially based on the Large Basins Model from the Brazilian Hydrological Research Institute (MGB-IPH) (Collischonn et al. 2007). MHD-INPE uses a probabilistic approach to relating the large-scale hydrological responses with self-organizing patterns, taking into account reservoirs with different capacities and topography effects over the basin drainage. It employs a catchment-based discretization with hydrological response units (HRU), simulating the interception, infiltration, percolation, evaporation, transpiration, storage and runoff responses for each regular grid HRU and sub-basin (SB). The soil is represented by three layers of varying depths that can be configured and/or calibrated. The land cover of each cell can be composed of a proportion of 12 land cover classes, while each one will have different parameters for further calculations. The infiltration is calculated using a statistical distribution of infiltration capacity or the depth of soil layers following the Xinanjiang model (Ren-Jun 1992; Ren-Jun and Liu 1995). The rainfall dispersion over the basin performed by the drainage system is modeled in terms of morphometric indices (Rodriguez-Iturbe and Valdes 1979). The water table level is calculated as a ratio of the amount of excess water over the field capacity in each reservoir, following the Distributed Hydrology Soil Vegetation Model (DHSVM) (Wigmosta et al. 2002). Also, it is assumed that the water table levels follow the local topography variations and the water transmissivity varies non-linearly with depth (Beven and Kirkby 1979; Iorgulescu and Musy 1997). The interception is simulated using Gash's analytical model (Gash et al. 1995). The root water uptake is modeled using a root distribution model (Jarvis 1989). The water routing between cells is performed according to the Muskingum-Cunge method (Cunge 1969).

\section{Model calibration}

Some model parameters were calibrated in order to achieve the best agreement between observed and simulated discharge: depth of each soil layer, hydraulic conductivity of soil layers, and coefficients regarding the time delay on groundwater recharge. The model was forced with the observational data on a daily time step for the period 1970-1990, following the SB order from upstream to downstream. The calibration process was performed using the Shuffled Complex Evolution (SCE-UA) optimization algorithm (Duan et al. 1992). Goodof-fitness was assessed by the Nash-Sutcliffe Efficiency (NSE) coefficient (Equation 1; Nash and Sutcliffe 1970), Root Mean Square Error (RMSE, Equation 2), and Normalized RMSE (NRMSE, Equation 3). The NSE determines the relative magnitude of residual variance from modeled to observed data in comparison to observed variance, ranges from $-\operatorname{Inf}$ to 1 , and a good model adjustment presents values close to 1 . The RMSE measures the difference between modeled and observed discharges and represents an absolute measure of error, whilst NRMSE is analogous to the coefficient of variation and can be compared between different models.

(1) NSE $=\frac{\sum_{i=1}^{n}\left(Q_{m}^{i}-Q_{o}^{i}\right)^{2}}{\sum_{i=1}^{n}\left(Q_{o}^{i}-\overline{Q_{o}}\right)^{2}}$

(2) $R M S E=\sqrt{\frac{1}{n} \sum_{i=1}^{n}\left(Q_{m}^{i}-Q_{o}^{i}\right)^{2}}$

(3) $N R M S E=\frac{R M S E}{\overline{Q_{o}}}$

where $Q_{m}^{i}$ and $Q_{o}^{i}$ represent the modeled and observed discharge of the $i$ th sample, respectively, $\overline{Q_{o}}$ represents the mean of observed discharge, and $n$ represents the total samples. 


\section{Experimental design}

The discharge simulation was performed by forcing the MHD-INPE hydrological model with ETA future climate projections for the periods 2011-2040, 2041-2070 and 20712099, and each of the model members: control (M1), low (M2), medium (M3) and high (M4).

After assessing the model calibration performance described previously, the last successfully calibrated sub-basin downward was used to perform the subsequent analysis. In order to explore overall modeled discharge tendencies, annual mean discharges were analyzed using descriptive statistics and linear regression fit. The statistics were obtained considering the mean and standard deviation between the model members regarding the difference of the modeled projections of 20712099 and historical datasets (1970-1990). Absolute and relative discharge differences were reported. Monthly means modeled discharges were plotted as a hidrogram to further explore the seasonal variations in discharge. Seasonal Kendall (SK) test was applied in order to test the projections for an existing trend between Dry and Wet seasons (Hirsch and Slack 1984). The seasons were defined regarding the river level and discharge dynamics: Wet from January to June; and Dry from July to December. The SK's null hypothesis $\left(\mathrm{H}_{0}\right)$ states that there is a common trend between seasons, against the alternative hypothesis $\left(\mathrm{H}_{1}\right)$ that states that there is a different trend between seasons. Descriptive statistics were also calculated considering the mentioned seasons.

Discharge and rainfall seasonal anomalies were calculated by taking the wet and dry seasons mean simulated values for each member and time period and subtracting the respective historical mean values. The discharge seasonal anomalies were analyzed using a two-way ANOVA in order to test the effects of the two factors on the discharge: time periods (2011-2040, 2041-2070 and 2071-2099), and model members (M1, M2, M3, and M4). For the statistically significant factors $(p<0.05)$, a post-hoc Tukey-Kramer test was applied to investigate which groups of means were different. In order to assess the differences between members, the test was applied separately to the members of each time period. In order to investigate the changes over time, the test was applied for each member independently. The relationship between rainfall and discharge seasonal anomalies was assessed using linear regression fit to investigate the effect of rainfall variations on the discharge according to different model members.

\section{RESULTS}

The model simulated the hydrological regimen pattern with good agreement, where the simulated and observed discharges approximately line up, except for sub-basin 11 (SB11) (Figure 2). The simulated discharge in SB11 between May and September was below the observed discharge (Figure 2k).
NSE (quantitative assessment of the calibration performance) ranged from 0.7 to 0.97 , RMSE (absolute errors in discharge) from 64 to $1,487 \mathrm{~m}^{3} \mathrm{~s}^{-1}$, and NRMSE (error deviations around the mean discharge) from 13.92 to $49.28 \%$, excluding SB11, which was not successfully calibrated (Table 1). Following the downstream sub-basins, a gradual increase in RMSE was observed. SB10 was the last downstream sub-basin that presented satisfactory calibration, with similar statistical indices to other SBs (NSE = 0.89; RMSE $=1,487.52 \mathrm{~m}^{3} \mathrm{~s}^{-1}$; NRMSE $=22.65 \%$ ). Therefore, $\mathrm{SB} 10$ results were used to investigate the discharge variations in relation to climate change.

The main meteorological variable means (radiation, atmospheric pressure, wind speed, temperature at dew point, air temperature and rainfall) simulated by the ETA-INPE model were successfully adjusted to observed data $\left(\mathrm{R}^{2}=\right.$ 0.99) using the proposed bias correction methods (Figure 3). Considering an average of the whole basin, the ETA projections presented an annual mean decrease in rainfall from $184 \mathrm{~mm} \mathrm{month}^{-1}$ in $1970-1990$ to $171.3(-6.9 \%)$, $164.3(-10.8 \%)$, and $163.7(-11.1 \%) \mathrm{mm} \mathrm{month}^{-1}$ in $2011-$ 2040, 2041-2070, and 2071-2099, respectively. Meanwhile, the air temperature increased from $27.2{ }^{\circ} \mathrm{C}$ to $28.8(6.1 \%)$, $30.3(11.5 \%)$, and $31.6(16.4 \%){ }^{\circ} \mathrm{C}$, dew point temperature increased from $20.8{ }^{\circ} \mathrm{C}$ to 21.8 (4.7\%), $22.6(8.8 \%)$, and 23.5 $(13.1 \%)^{\circ} \mathrm{C}$, wind speed increased from $2.28 \mathrm{~m} \mathrm{~s}^{-1}$ to 2.35 (3.1\%), $2.43(6.6 \%)$, and $2.47(8.4 \%) \mathrm{m} \mathrm{s}^{-1}$, between the same time periods. Atmospheric pressure and radiation presented less than 1\% variation between 1970-1990 and 2071-2099.

When forcing the MHD-INPE model with future climate projections, a negative trend on discharge during the 21 st century was observed (Figure 4). The projection mean response represented an overall discharge decrease of 1,704 $\pm 550 \mathrm{~m}^{3} \mathrm{~s}^{-1}(-27 \pm 8 \%)$ by the end of the 21 st century. All members presented negative slopes, whilst M2 showed a shallow slope, M1 an intermediate to steep slope, and M3 and M4 steeper slopes. The Seasonal Kendall test indicated a non-significant trend between seasons for M2 ( $\mathrm{p}=0.43)$, and significant differences for M1, M3, and M4.

The model members presented similar climatology over time, except for M2, which presented higher discharge than the other members during the dry season in 2041-2099 (Figure 5c and 5d). When comparing the 2071-2099 members mean discharge to the historical values, we observed a discharge decrease of $2,471 \pm 822 \mathrm{~m}^{3} \mathrm{~s}^{-1}(-25 \pm 8 \%)$ in the wet season, and $937 \pm 358 \mathrm{~m}^{3} \mathrm{~s}^{-1}(-36 \pm 14 \%)$ in the dry season.

Dry and wet seasons differed significantly in discharge between periods (two-factor ANOVA) (Table 2). The wet season did not differ significantly among members $(\mathrm{p}=0.45)$ nor did the period/member interaction $(\mathrm{p}=0.42)$. The dry season differed significantly among members, and period/member interactions. 

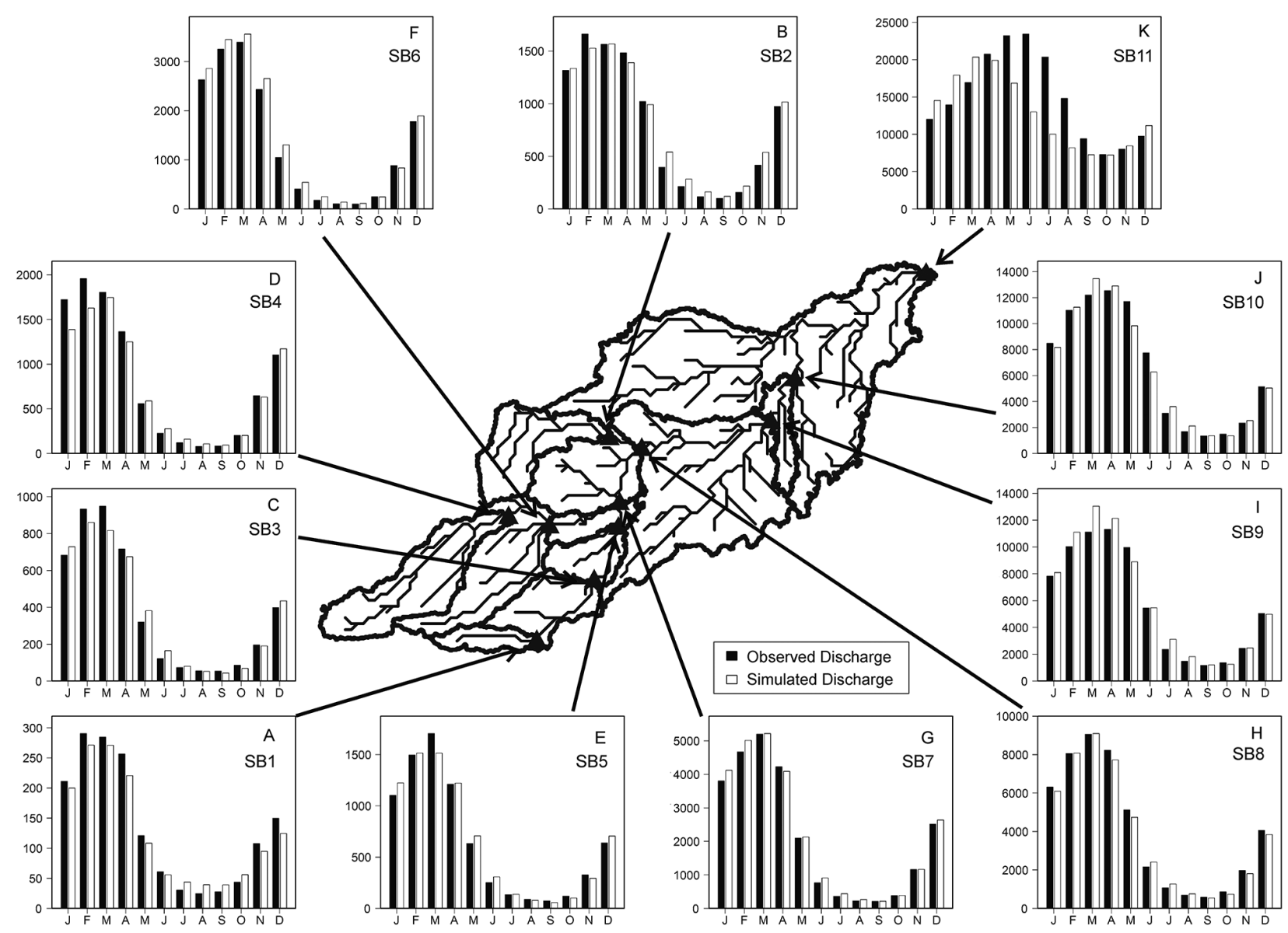

Figure 2. Representation of the Purus Basin, its sub-basins (SB) and rivers with the observed and simulated discharge from SB 1 to 11 (a)-(k) for $1970-1990$.

Table 1. The performance of the MHD-INPE model to simulate the discharge between 1970-1990 in the Purus Basin.

\begin{tabular}{lccc}
\hline $\begin{array}{l}\text { Sub-Basin } \\
(\mathrm{SB})\end{array}$ & $\begin{array}{c}\text { Nash-Sutcliffe } \\
\text { Efficiency (NSE) }\end{array}$ & $\begin{array}{c}\text { RMSE } \\
\left(\mathrm{m}^{3} \mathrm{~s}^{-1}\right)\end{array}$ & $\begin{array}{c}\text { NRMSE } \\
(\%)\end{array}$ \\
\hline 1 & 0.70 & 64.43 & 49.28 \\
2 & 0.97 & 107.53 & 13.92 \\
3 & 0.84 & 150.51 & 39.55 \\
4 & 0.85 & 309.43 & 37.31 \\
5 & 0.85 & 239.31 & 36.93 \\
6 & 0.85 & 525.77 & 38.32 \\
7 & 0.92 & 549.62 & 26.30 \\
8 & 0.94 & 815.26 & 20.31 \\
9 & 0.89 & $1,350.83$ & 23.30 \\
10 & 0.89 & $1,487.52$ & 22.65 \\
11 & - & - & - \\
\hline
\end{tabular}

The four members indicated basin discharge reduction until the end of the century (Figure 6). The difference between dry and wet seasons before 2040 was subtle (around $8 \%$ ), but an abrupt decrease in discharge is observed for M1, M3, and M4 after 2040, particularly in the dry season (Figure 6a). In general, there was a gradual discharge decrease in the wet season between 2011 and 2099 and a comparatively rapid discharge decline in the dry season, regarding M3 and M4.

The transition from 2011-2040 to 2041-2070 presented a $10-20 \%$ reduction in mean discharge during the dry season, although only the M3 and M4 members showed a significant difference. There was no significant difference between the members in both dry and wet seasons of the 2011-2040 time period $(\mathrm{p}=0.99)$. Yet the responses in 2041-2070 presented a significant difference between M2 and the other members only during the dry season. The periods 2071-2099 and 20412070 had similar results. The only significant difference in the 
ACTA

AMAZONICA

Assessment of climate change impacts on water resources of the Purus Basin in the southwestern Amazon

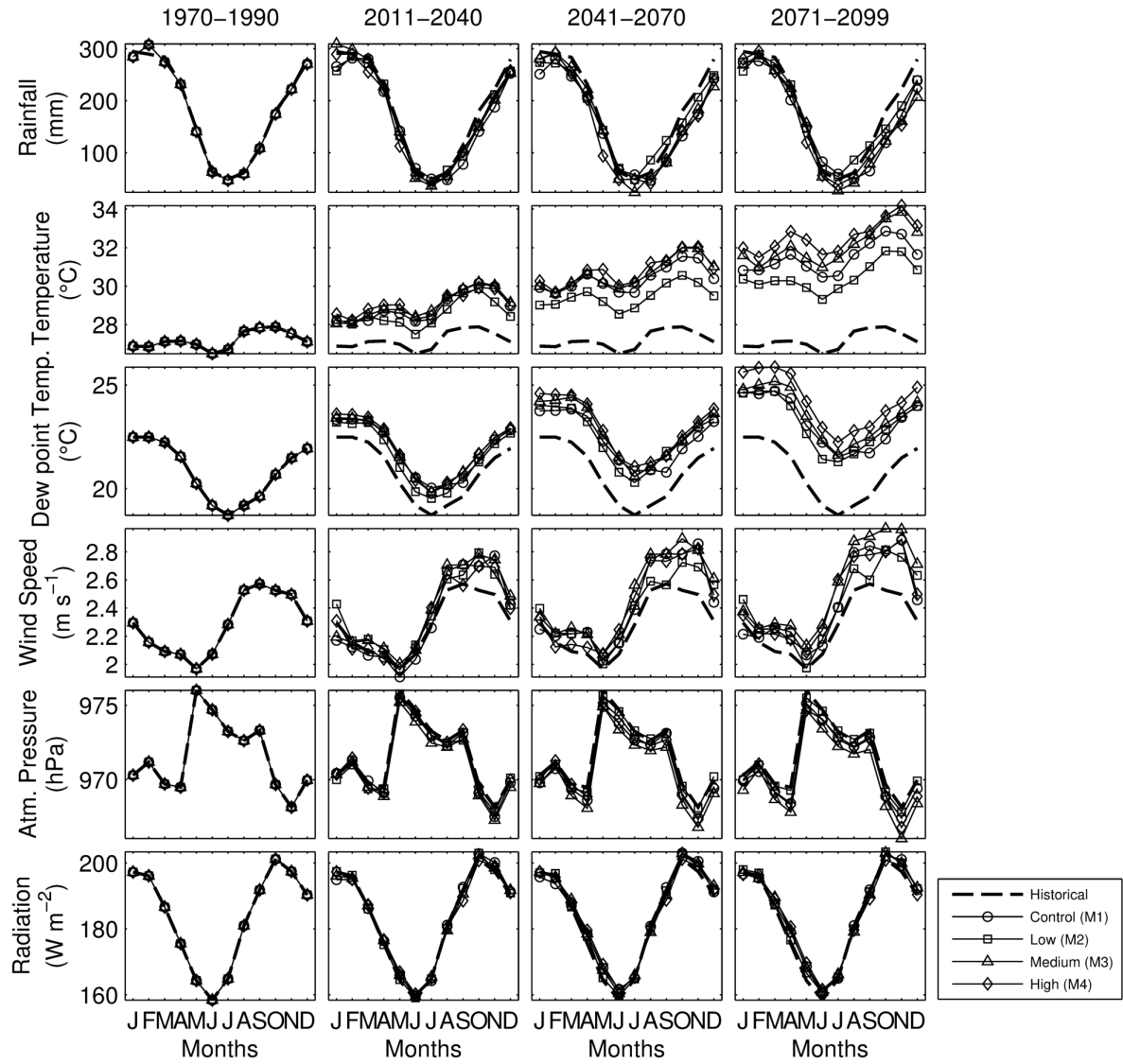

Figure 3. Climatologies of meteorological variables from modeled historical ETA data (1970-1990; dashed lines) and future climate projections (2011-2040, 2041-2070, and 2071-2099; solid lines) for M1, M2, M3 and M4 members of the ETA-INPE/HadCM3 model corresponding to the A1B-AR4/IPCC scenario in the Purus Basin. The values correspond to an average of the whole basin response.

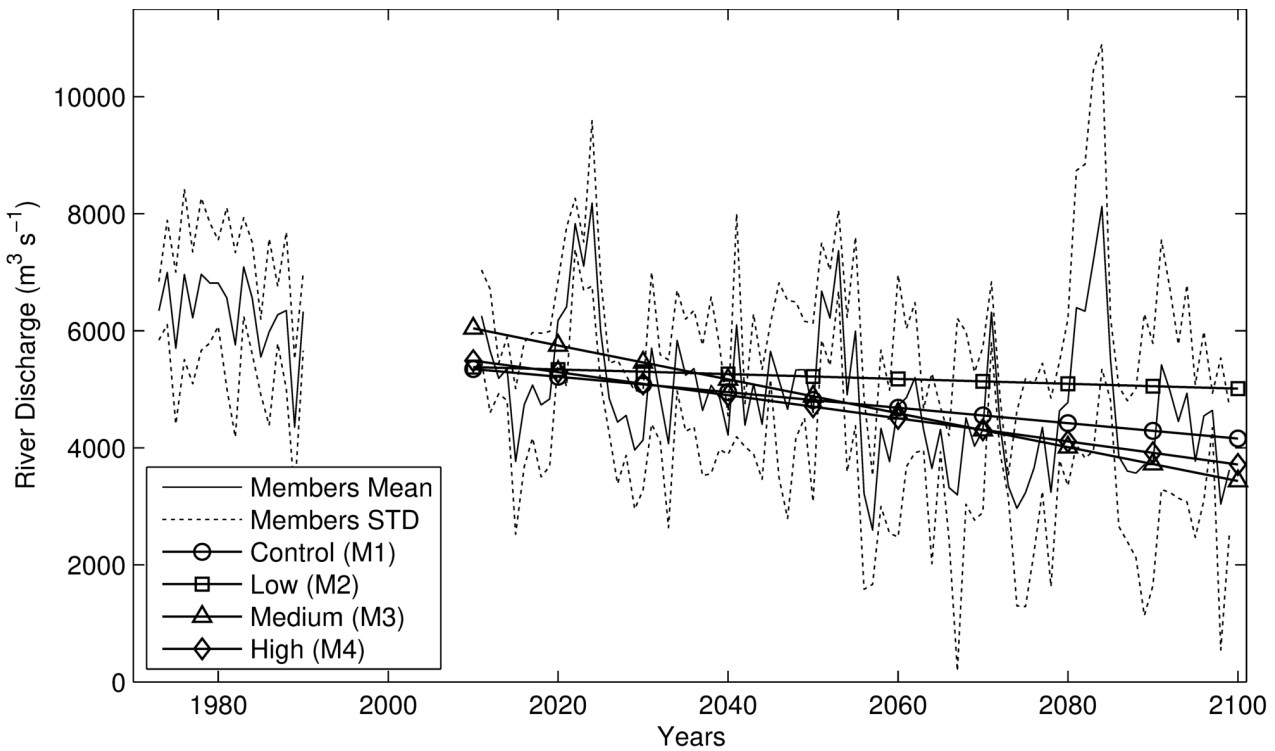

Figure 4. Historical and projected ETA members annual mean discharges (solid line without markers) and standard deviation between members (dashed line) for the Purus Basin during the 21st century, and linear fits for M1, M2, M3 and M4 members (solid lines with markers) of the ETA-INPE/HadCM3 model. 

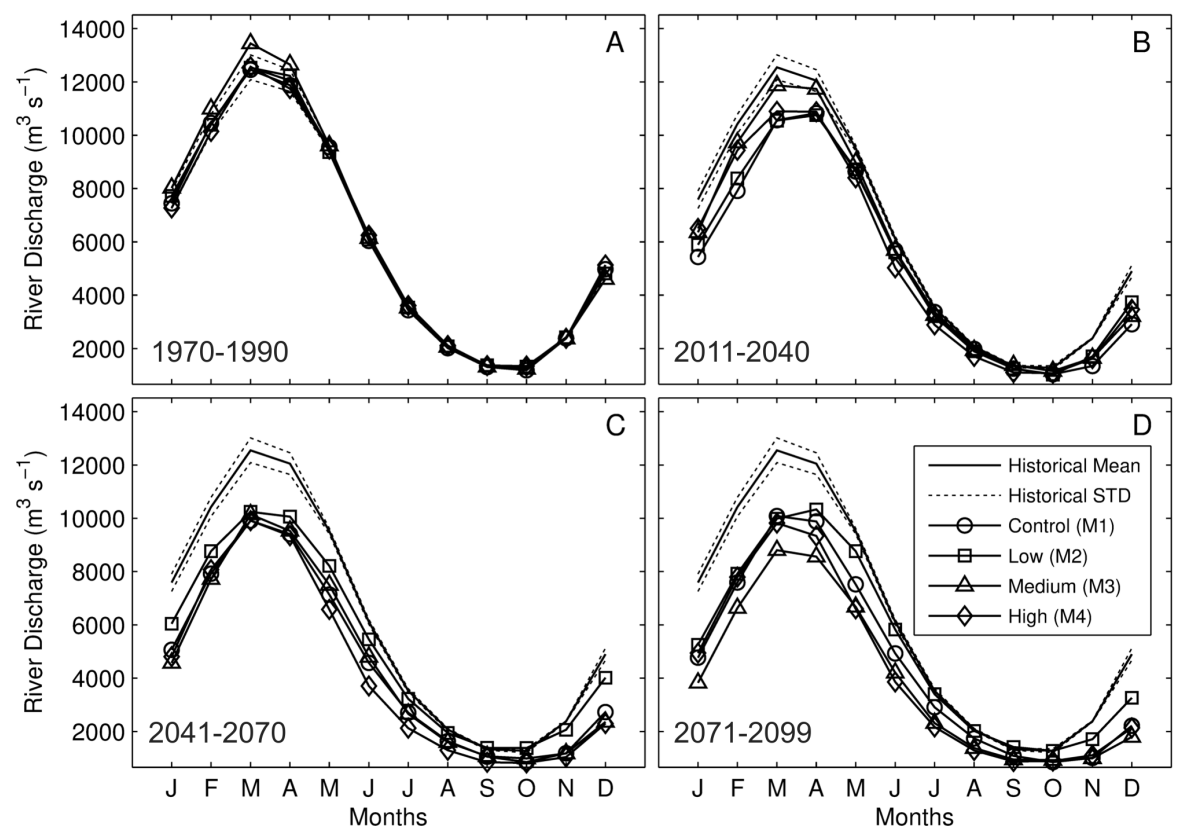

Figure 5. Climatologies of modeled discharge for M1, M2, M3 and M4 members of the ETA-INPE/HadCM3 model regarding the A1B-AR4/IPCC scenario (solid lines with markers) in the Purus Basin, for: (a) 1970-1990, (b) 2011-2040, (c) 2041-2070, and (d) 2071-2099; and ETA mean historical discharge (solid lines without markers) and standard deviation (dashed lines) as reference for 1970-1990.
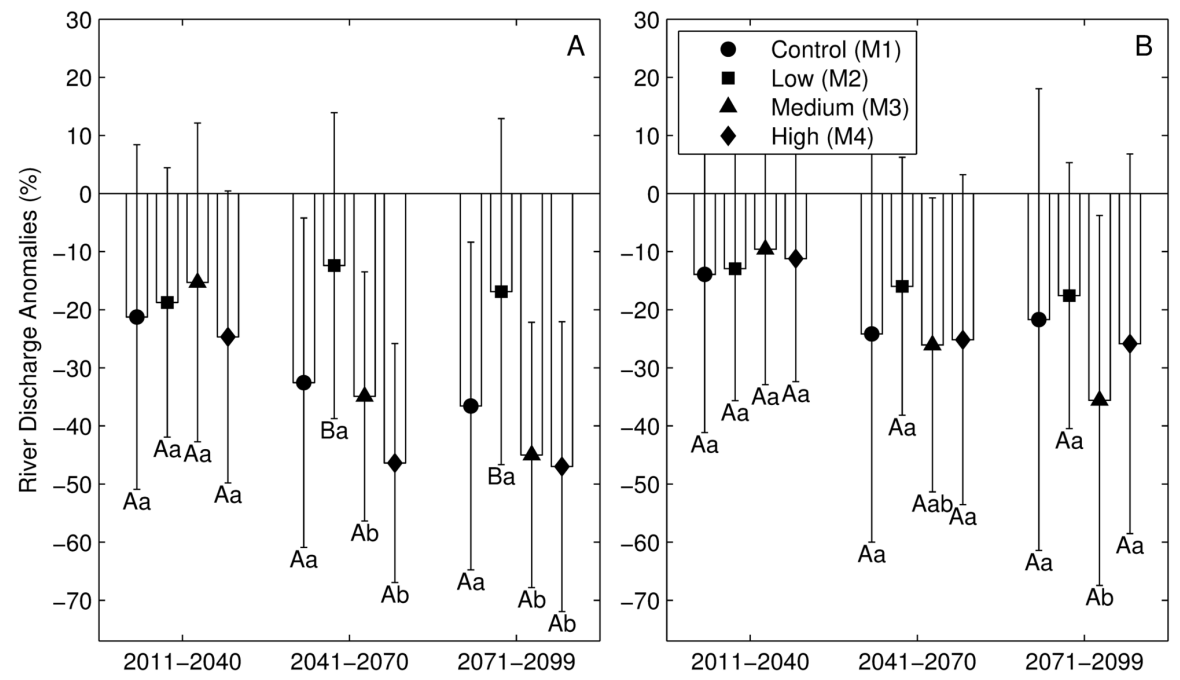

Figure 6. Purus Basin average (columns) and standard deviation (whiskers) discharge anomalies. The simulation used the MHD-INPE hydrological model forced by ETA data for M1 to M4 model members (A1B-AR4/IPCC scenario for 2011-2040, 2041-2070, and 2071-2099 time periods) during the (a) dry season, and (b) wet season. The significance was tested using Tukey-Kramer post-hoc test where A,B represents no statistical difference among members in each time period $(\alpha=0.05)$, and a,b represents no statistical difference of each member among time periods $(\alpha=0.05)$. 
wet season was M3 from 2011-2040 to 2071-2099. Other members did not differ significantly between time periods.

The rainfall/discharge relationship of the model members was assessed for the dry (Figure 7a) and wet (Figure 7b) seasons using linear regression. Rainfall was able to explain 59-75\% discharge changes in the dry season (around 18\% RMSE) and 60-69\% discharge changes in the wet season (around $22 \%$ RMSE). The small differences in correlation coefficients among members and seasons were assumed to be negligible. Nevertheless, the average slope of the regression fits was less steep in the dry season (slope $=1.5$ ) than in the wet season (slope $=2.1$ ), and all slopes were statistically significant. The wet season slope trend was positive reflecting air temperature increase from M2, M1, and M3 to M4 (Figure 3 and 7b). In the dry season, M4 had the steeper slope, yet M1, and not M2, had the shallower slope (Figure 7a).

Table 2. Two-way Analysis of Variance (ANOVA) of seasonal discharge anomalies regarding the factors time period (TP) and model member (MM).

\begin{tabular}{|c|c|c|c|c|c|c|}
\hline Season & Source of Variation & Sum of Squares & Degrees of Freedom & Mean Square & $\mathrm{F}$ & $\mathrm{P}$ \\
\hline \multirow{5}{*}{ Wet } & TP & $10,280.2$ & 2 & $5,140.09$ & 7.59 & 0.0006 \\
\hline & MM & $1,787.0$ & 3 & 595.66 & 0.88 & 0.4517 \\
\hline & TP MM & $4,075.9$ & 6 & 679.32 & 1.00 & 0.4228 \\
\hline & Error & $232,873.1$ & 344 & 676.96 & & \\
\hline & Total & $248,992.5$ & 355 & & & \\
\hline \multirow{5}{*}{ Dry } & TP & $17,535.5$ & 2 & $8,767.73$ & 12.55 & 0.0000 \\
\hline & $\mathrm{MM}$ & $25,697.1$ & 3 & $8,565.70$ & 12.26 & 0.0000 \\
\hline & TP MM & $11,224.7$ & 6 & $1,870.78$ & 2.68 & 0.0149 \\
\hline & Error & $240,337.0$ & 344 & 698.65 & & \\
\hline & Total & $294,562.5$ & 355 & & & \\
\hline
\end{tabular}

Table 3. Summary of Tukey-Kramer test regarding time period and model member comparison.

\begin{tabular}{|c|c|c|c|c|c|c|c|}
\hline \multirow[b]{2}{*}{ Season } & \multicolumn{3}{|c|}{ Members comparison } & \multicolumn{4}{|c|}{ Time period comparison } \\
\hline & $2011-2040$ (T1) & $2041-2070$ (T2) & 2071-2099 (Т3) & Control (M1) & Low (M2) & Medium (M3) & High (M4) \\
\hline Wet & NS & NS & NS & NS & NS & $\mathrm{T} 1=\mathrm{T} 2, \mathrm{~T} 2=\mathrm{T} 3, \mathrm{~T} 1 \neq \mathrm{T} 3$ & NS \\
\hline Dry & NS & $\mathrm{M} 2<\mathrm{M} 1 / \mathrm{M} 3 / \mathrm{M} 4$ & $\mathrm{M} 2<\mathrm{M} 1 / \mathrm{M} 3 / \mathrm{M} 4$ & NS & NS & $\mathrm{T} 1<\mathrm{T} 2 / \mathrm{T} 3$ & $\mathrm{~T} 1<\mathrm{T} 2 / \mathrm{T} 3$ \\
\hline
\end{tabular}

NS $=$ no statistical difference between members or time periods $(\alpha=0.05)$.
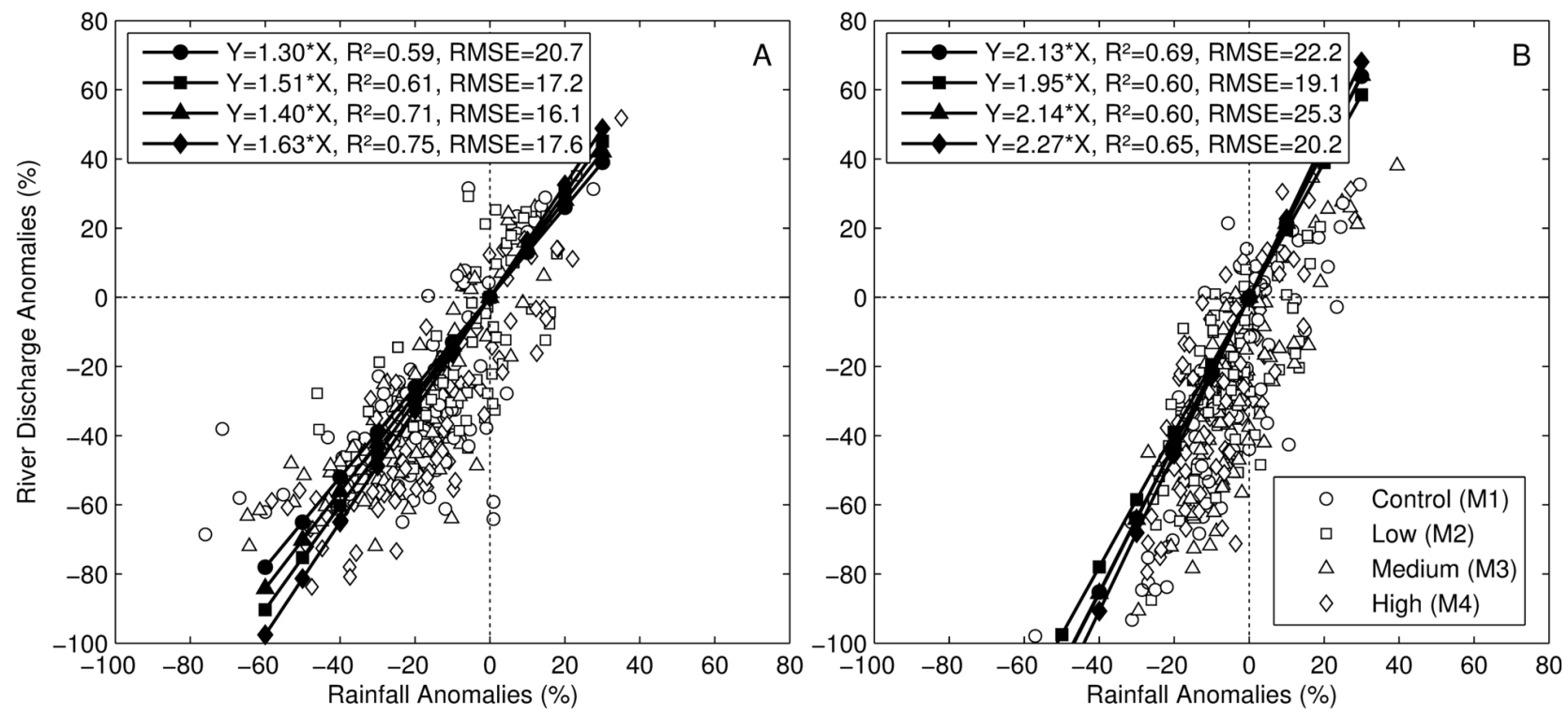

Figure 7. Relationship between anomalies of rainfall and simulated discharge regarding model members (markers) for (a) dry season, and (b) wet season; and linear regression fit (solid lines with markers) 


\section{DISCUSSION}

\section{Model calibration}

In SB11 the model likely underestimated the discharge between May and September due to the backwater effect of the Solimóes River upon the Purus Basin, which occurs in the wet season and directly affects the gauge station measurements (Meade 1991). Since this phenomenon is not predicted by the model, additional calibration rounds on SB11 would not produce better results. The pattern of increase of RMSE downwards the basin was conditioned by the increased volume of water drained from the sub-basins towards the basin outlet, whilst NRMSE is a relative measure of error around the mean discharge and did not necessarily increase downwards.

The last sub-basin downwards that could be calibrated was the SB10, with a similar or better performance than most sub-basins. The mean discharge for that sub-basin is one of the largest in the sub-basin (mean discharge $=6,567.41 \mathrm{~m}^{3} \mathrm{~s}^{-1}$ ), and its high absolute error deviation (22.65\%) was expected since this sub-basin concentrates all the water from the upward sub-basins. Our calibration results are similar to those from other studies using MHD-INPE for Amazon basins such as the Tapajós (Mohor et al. 2015) and Madeira rivers (Siqueira Júnior et al. 2015).

\section{Purus basin future climate}

The climate variable changes over time proved to be adequate as proposed by A1B-AR4/IPCC (Solomon et al. 2007). The air temperature and dew point temperature followed an overall increasing trend from M2, M1, M3 to M4, as expected (Chou et al. 2012). Rainfall and wind speed varied substantially among time periods, but without forming a clear trend among model members.

The differences among ETA model members are related to disturbances in the boundary conditions of the climate model by using different combinations of atmospheric and terrestrial parameter settings. Even though the members are forced with the same $\mathrm{CO}_{2}$ concentrations, the resulting meteorological variables present spatial-temporal variations, which is expected when running long-term climate iterations (Chou et al. 2012).

\section{Overall discharge tendency and climatology}

The projected impact of climate change on the Purus Basin is a $-27 \%$ river discharge by the end of the 21 st century, considering the overall response among climate model members. This result was probably mainly conditioned by the combined effect of (1) an overall $10.8 \%$ decrease in rainfall, which directly affects the total water that enters the basin; (2) an overall $4.4^{\circ} \mathrm{C}$ increase in air temperature, following a gradient from M2, M1, M3 to M4, which affects the water removal from soil and plants through evapotranspiration; and (3) a $8.4 \%$ increase in wind speed, which is more accentuated in the dry season, through an increase in the transport of water vapor from evaporative surfaces, enhancing the evapotranspiration process when the air is not saturated. Similar river discharge reductions were observed in other studies of Amazonian sub-basins (Mohor et al. 2015; Siqueira Júnior et al. 2015).

The SK trend test pointed to an expected trend of seasonal variability over time, with a temperature increase, which may lead to a higher occurrence of extreme events. This change in seasonality is probably related to an increase in the length of the dry season, which in turn is related to the warming of the tropical North Atlantic Sea (Marengo et al. 2011; Siqueira Júnior et al. 2015).

\section{Dry-wet seasonal anomaly analysis}

The differences among model members seem to have an impact only in the dry season, specifically as a function of $\mathrm{M} 2$, through a lower increase in temperature over time periods, as compared to the other members. This is the main difference between M2 and the other model members considering the meteorological variables analyzed in this study. This difference likely explains the significant anomalies between M2 and the other model members in Figure 6.

The rapid decline in discharge during the dry season, as compared to the more gradual decline in the wet season, can be associated with the greater increase in the wind speed field observed in the dry season in 2011-2040 and 2041-2070. This is explained by the inverse relationship between wind speed and aerodynamic resistance (Monteith 1965), which facilitates the transfer of heat and water vapor from the evaporating surface into the air. Since water and radiation are not a limitation factor in the Purus Basin, probably greater evapotranspiration occurs, resulting in less discharge.

The basin faces a huge decrease in the absolute amount of water flow, both in the wet season $(-25.1 \%$ discharge), and even higher in the dry season $(-36.3 \%)$, which is likely to impact significantly the basin's ecosystems and human population. The drier the basin becomes, combined with higher temperature projections of the climate scenarios, the higher are the probabilities of forest fires, which amplifies tree mortality in future extreme drought events (Aragão et al. 2008; Barlow and Peres 2008). In the long run, vegetation changes to seasonal forests or savannas may be favored (Malhi et al. 2009; Nobre and Borma 2009).

\section{Significant changes in rainfall and discharge}

Rainfall and discharge seem to have a linear relationship across members, with a steeper slope indicating a greater impact of rainfall on discharge. A reduction of $11 \%$ in rainfall is projected to cause an average decrease of 15 and $21 \%$ discharge during the dry and wet seasons, respectively. The stronger response of discharge to rainfall in the wet 
season could be due to the difference of $-11 \%$ in absolute water content between the seasons. The anomaly in the rainfall/discharge relationship is probably associated with an increment in evapotranspiration due to rising temperatures.

In the Tapajós River Basin, an average of $11 \%$ decrease in rainfall represents an approximate $37 \%$ decrease in river discharge over both seasons (Mohor et al. 2015). Our results project a lower impact of rainfall and temperature on discharge in the Purus Basin, possibly owed to forest cover, which is higher in the Purus Basin (5.4\% deforestation), than in the Tapajós Basin (20\% deforestation) (Trancoso et al. 2009). The forest cover enhances water infiltration processes, and retards soil water flux, hence resulting in less discharge and more water retention (Lima et al. 2014).

\section{CONCLUSIONS}

The MHD-INPE hydrological model was forced with climate projections from the regional ETA-INPE model driven by four members of an ensemble of the HadCM3 global model regarding the $\mathrm{A} 1 \mathrm{~B}-\mathrm{AR} 4 / \mathrm{IPCC}$ scenario, in order to assess the impacts of climate change on the hydrological regime of the Purus River Basin, in the western Amazon, throughout the 21st century. The MHD-INPE model was able to simulate the hydrological regime of the Purus Basin and predict an overall reduction of $27 \%$ in discharge by the end of the 21 st century, with differing dry and wet season patterns, as well as changes in seasonality trends. The long-term effects projected for future climate in the basin were mainly related to a substantial decrease in rainfall, and an increase in temperature and wind speed. The predicted discharge decrease in the wet season is gradual along 2011-2099 and higher in absolute values, while in the dry season the trend is abrupt and higher in relative values. The projected climate change in the Purus Basin has severe consequences on its water balance and probably will greatly impact ecosystem maintenance and human subsistence. In a climate change adaptation process, the preservation of the natural forest cover of the Purus Basin may have great importance in water retention.

\section{ACKNOWLEDGEMENTS}

The first author thanks the Conselho Nacional de Desenvolvimento Científico e Tecnológico (CNPq) for grant number 302561/2014-5. We also thank two anonymous reviewers and editor who contributed immensely to earlier versions of the manuscript.

\section{REFERENCES}

Aragão, L.E.O.C.; Malhi, Y.; Barbier, N.; Lima, A.A.; Shimabukuro, Y.; Anderson, L.; Saatchi, S. 2008. Interactions between rainfall, deforestation, and fires during recent years in the Brazilian
Amazonia. Philosophical Transactions of the Royal Society of London, 363: 1779-85.

Bárdossy, A.; Pegram, G. 2011. Downscaling precipitation using regional climate models and circulation patterns toward hydrology. Water Resources Research, 47: W04505.

Barlow, J.; Peres, C.A. 2008. Fire-mediated dieback and compositional cascade in an Amazonian forest. Philosophical Transactions of the Royal Society of London, 363: 1787-1794.

Beven, K.J.; Kirkby, M.J. 1979. A physically based, variable contributing area model of basin hydrology. Hydrological Sciences Bulletin, 24: 43-69.

Borma, L.S.; Tomasella, J.; Roballo, S.T.; Cuartas, L.A.; Rodrigues, D.A.; Marengo, J. A.; Nobre, C.A. 2013. Impactos dos extremos de seca e cheia sobre os recursos hídricos amazônicos e açôes da Defesa Civil. In: Borma, L.S.; Nobre, C.A. (Ed.). Secas na Amazônia: causas e consequências. 1st ed. Oficina de Textos, São Paulo, p.306-325.

Brazilian National Agency of Water Resources (ANA). 2016. HIDROWEB - Hydrological database. (http://www.snirh.gov. br/hidroweb). Accessed on 01/05/2016.

Brazilian National Meteorological Institute (INMET). 2016. Meteorological data. (http://www.inmet.gov.br/html/rede_obs. php). Accessed on 01/05/2016.

Chou, S.C.; Marengo, J.A.; Lyra, A.A.; et al. 2012. Downscaling of South America present climate driven by 4-member HadCM3 runs. Climate Dynamics, 38: 635-653.

Collischonn, W.; Allasia, D.; Da Silva, B.C.; Tucci, C.E.M. 2007. The MGB-IPH model for large-scale rainfall runoff modelling. Hydrological Sciences Journal, 52: 878-895.

Costa, S.M.; Brondízio, E.S. 2011. Cities Along the Floodplain of the Brazilian Amazon: Characteristics and Trends. In: PinedoVasquez, M.; Ruffino, M.L.; Padoch, C.; Brondízio, E.S. (Ed.). The Amazon Várzea. Springer, Dodrecht, Netherlands. p.83-97.

Culf, A.D.; Esteves, J.L.; Marques Filho, A.O.; Rocha, H.R. 1996. Radiation, temperature and humidity over forest and pasture in Amazonia. In: Gash, J.H.C.; Nobre, C.A.; Roberts, J.M.; Victoria, R.L. Amazonian deforestation and climate. John Wiley \& Sons, New York, p.175-191.

Cunge, J.A. 1969. On the subject of a flood propagation computational method (Muskingum Method). Journal of Hydraulic Research, 7: 205-230.

Dorman, J.L.; Sellers, P.J. 1989. A global climatology of albedo, roughness length and stomatal resistance for atmospheric general circulation models as represented by the Simple Biosphere Model (SiB). Journal of Applied Meteorology, 28: 833-855.

Doyle, M.E.; Tomasella, J.; Rodriguez, D.A.; Chou, S.C. 2013. Experiments using new initial soil moisture conditions and soil map in the Eta model over La Plata Basin. Meteorology and Atmospheric Physics, 121: 119-136.

Duan, Q.; Sorooshian, S.; Gupta, H.V.; Gupta, V. 1992. Effective and efficient global optimization for conceptual rainfall-runoff models. Water Resources Research, 28: 1015-1031. 
Feddersen, H.; Andersen, U. 2005. A method for statistical downscaling of seasonal ensemble predictions. Tellus. Series A, Dynamic meteorology and oceanography, 57: 398-408.

FUNASA. 2006. Relatório anual de gestão Alto Purus. Rio Branco. (https://sis.funasa.gov.br/portal/publicacoes/pub1305.pdf). Acessed on 01/05/2016.

Gash, J.H.C.; Nobre, C.A. 1997. Climatic effects of Amazonian deforestation: some results from ABRACOS. Bulletin of the American Meteorological Society, 78: 823-830.

Hamski, J.; Lefavour, G.; Alsdorf, D.; Pavelsky, T. 2006. Estimating water slope in Amazon River tributaries using the shuttle radar topography mission digital elevation model. $A G U$ Fall Meeting Abstracts, 87: \#H23A-1461.

Hirsch, R.M.; Slack, J.R. 1984. A nonparametric trend test for seasonal data with serial dependence. Water Resources Research, 20: 727-732.

Instituto Brasileiro de Geografia Estatística (IBGE). 1992. Manual técnico de vegetaçâo brasileira. Rio de Janeiro, $92 \mathrm{p}$.

Instituto Nacional de Pesquisas Espaciais (INPE). 2016. TerraView 4.2.2 Hidro 0.3.8. (http://www.dpi.inpe.br/terraview/index. php). Accessed on 01/04/2016.

Iorgulescu, I.; Musy, A. 1997. Generalization of TOPMODEL for a power law transmissivity profile. Hydrological Processes, 11: $1353-1355$.

Jarvis, N.J. 1989. A simple empirical model of root water uptake. Journal of Hydrology, 107: 57-72.

Land Data Assimilation Systems - NASA (LDAS-NASA). 2014. NLDAS Vegetation Parameters. (http://ldas.gsfc.nasa.gov/nldas/ NLDASmapveg.php). Accessed on 15/06/2014.

Leite, C.C.; Costa, M.H.; de Lima, C.A.; Ribeiro, C.A.A.S.; Sediyama, G.C. 2011. Historical reconstruction of land use in the Brazilian Amazon (1940-1995). Journal of Land Use Sciences, 6: 33-52.

Lenderink, G.; Buishand, A.; Van Deursen, W. 2007. Estimates of future discharges of the river Rhine using two scenario methodologies: direct versus delta approach. Hydrology and Earth System Sciences, 11: 1145-1159.

Lewis, S.L.; Brando, P.M.; Phillips, O.L.; van der Heijden, G.M.F.; Nepstad, D. 2011. The 2010 Amazon drought. Science, 331: 554.

Lima, L.S.; Coe, M.T.; Soares Filho, B.S.; et al. 2014. Feedbacks between deforestation, climate, and hydrology in the Southwestern Amazon: implications for the provision of ecosystem services. Landscape Ecology, 29: 261.

Malhi, Y.; Aragão, L.E.O.C.; Galbraith, D.; Huntingford, C.; Fisher, R.; Zelazowski, P.; Sitch, S.; McSweeney, C.; Meir, P. 2009. Exploring the likelihood and mechanism of a climate-changeinduced dieback of the Amazon rainforest. PNAS, Proceedings of the National Academy of Sciences, 106: 20610-5.

Marengo, J.A.; Tomasella, J.; Alves, L.M.; Soares, W.R.; Rodriguez, D.A. 2011. The drought of 2010 in the context of historical droughts in the Amazon region. Geophysical Research Letters, 38: L12703.
Mateus, P.; Borma, L.S.; Silva, R.D.; Nico, G.; Catalão, J. 2016. Assessment of two techniques to merge ground-based and TRMM rainfall measurements: a case study about Brazilian Amazon Rainforest. GIScience \& Remote Sensing, 53: 689-706.

McClain, M.E.; Naiman, R.J. 2008. Andean Influences on the Biogeochemistry and Ecology of the Amazon River. Bioscience, 58: 325 .

Meade, R.H.; Rayol, J.M.; Conceição, S.C.; Natividade, J.R.G. 1991. Backwater Effects in the Amazon River of Basin. Environmental Geology and Water Sciences Journal, 18: 105-114.

Melack, J.M.; Hess, L.L. 2010. Remote sensing of the distribution and extent of wetlands in the Amazon basin. In: Junk, W.J.; Piedade, M.T.F.; Wittmann, F.; Schöngart, J.; Parolin, P. (Ed.). Amazonian floodplain forests: ecophysiology, biodiversity and sustainable management. Ecological studies. v. 210. Springer, New York, p.43-60.

Melack, J.M.; Novo, E.M.L.M.; Forsberg, B.R.; Piedade, M.T.F.; Maurice, L. 2009. Floodplain ecosystem processes. In: Keller, M.E.A. (Ed.). Amazonia and global change. American Geophysical Union Books, Washington, p.525-542.

Mohor, G.S.; Rodriguez, D.A.; Tomasella, J.; Siqueira Júnior, J.L. 2015. Exploratory analyses for the assessment of climate change impacts on the energy production in an Amazon run-of-river hydropower plant. Journal of Hydrology Regional Studies, 4: 41-59.

Monteith, J.L. 1965. Evaporation and Environment. In: Foff, G.E. (Ed.). The state and movement of water in living organism. 19th Symposium, Society of Experimental Biology, Swansea, Cambridge University Press, p.205-234.

Nash, J.E.; Sutcliffe, J.V. 1970. River flow forecasting through conceptual models part I -A discussion of principles. Journal of Hydrology, 10: 282-290.

Nepstad, D.; Lefebvre, P.; Da Silva, U.L.; Tomasella, J.; Schlesinger, P.; Solórzano, L.; Moutinho, P.; Ray, D.; Benito, J.G. 2004. Amazon drought and its implications for forest flammability and tree growth: A basin-wide analysis. Global Change Biology, 10: 704-717.

Nobre, C.A.; Borma, L.D.S. 2009. “Tipping points” for the Amazon forest. Current Opinion in Environmental Sustainability, 1: $28-36$.

Osuna, V.R.; Börner, J.; Cunha, M. 2014. Scoping adaptation needs for smallholders in the Brazilian Amazon: a municipal level case study. Change Adaptation Socioecological Systems, 1: 12-25.

Peel, B.L.; Finlayson, B.L.; McMahon, T.A. 2007. Updated world map of the Köppen-Geiger climate classification.pdf. Hydrology and Earth System Sciences, 11: 1633-1644.

Phillips, O.L.; Aragão, L.E.O.C.; Lewis, S.L.; Fisher, J.B.; Lloyd, J.; López-gonzález, G.; et al. 2009. Drought Sensitivity of the Amazon Rainforest. Science, 323: 1344-1347.

Piedade, M.T.F.; Schöngart, J.; Wittman, F.; Parolin, P.; Junk, W.J. 2013. Impactos da inundação e seca na vegetação de áreas alagáveis amazônicas. In: Borma, L.S.; Nobre, C.A. (Ed.). Secas na Amazônia: causas e consequências. 1st ed. Oficina de Textos, São Paulo, p.268-297. 


\section{ACTA}

Pinho, P.F.; Orlove, B.; Lubell, M. 2012. Overcoming Barriers to Collective Action in Community-Based Fisheries Management in the Amazon. Human Organization, 71: 99-109.

Reid, J.; De Sousa, W.C. 2005. Infrastructure and conservation policy in Brazil. Conservation Biology, 19: 740-746.

Ren-Jun, Z. 1992. The Xinanjiang model applied in China. Journal of Hydrology, 135: 371-381.

Ren-Jun, Z.; Liu, X.R. 1995. The Xinanjiang model. In: Singh, V.P. (Ed.). Computer Models of Watershed Hydrology. Water Resources Publication, Highlands Ranch, p.215-232.

Rodriguez, D.A. 2011. Impactos dos padröes espaciais da vegetação nas variáveis atmosférica e terrestre do ciclo hidrológico, em bacia de floresta amazônica. Doctoral thesis, Instituto Nacional de Pesquisas Espaciais, São José dos Campos, São Paulo.

Rodriguez, D.A.; Tomasella, J. 2015. On the ability of large-scale hydrological models to simulate land use and land cover change impacts in Amazonian basins. Hydrological Sciences Journal, 1: 150521041017004.

Rodríguez-Iturbe, I.; Valdés, J.B. 1979. The geomorphologic structure of hydrologic response. Water Resources Research, 15: 1409-1420.

Seibert, J.; McGlynn, B.L. 2007. A new triangular multiple flow direction algorithm for computing upslope areas from gridded digital elevation models. Water Resources Research, 43: W04501.

Shepard, D. 1968. A two-dimensional interpolation function for irregularly-spaced data. In: Proceedings of the 1968 ACM National Conference, New York, p. 517-524.

Siqueira Junior, J.L.; Tomasella, J.; Rodriguez, D.A. 2015. Impacts of future climatic and land cover changes on the hydrological regime of the Madeira River basin. Climate Change, 129: 117-129.

Solomon, S.D; Qin, M.; Manning, Z.; Chen, M.; Marquis, K.B.; Averyt, M.T.; et al. 2007. Summary for Policymakers. In: Climate Change. 2007. The Physical Science Basis. Contribution of Working Group I to the Fourth Assessment Report of the Intergovernmental Panel on Climate Change. Cambridge University Press, New York, 996p.

Sousa Júnior, W.C.; Waichman, A.V.; Jaime, A.L.G.; Sinisgalli, P.A.A. 2006. Gestão das águas na Amazônia: a bacia do rio Purus. In: Anais I Workshop Gestão Estratégica de Recursos Hidricos. Brasília, 4p.
Teutschbein, C.; Seibert, J. 2013. Is bias correction of regional climate model (RCM) simulations possible for non-stationary conditions. Hydrology and Earth System Sciences, 17: 5061-5077.

Trancoso, R.; Carneiro Filho, A.; Tomasella, J.; Schietti, J.; Forsberg, B.R.; Miller, R.P. 2009. Deforestation and conservation in major watersheds of the Brazilian Amazon. Environmental Conservation, 36: $277-288$

Ubarana, V.N. 1996. Observation and modelling of rainfall interception at two experimental sites in Amazônia. In: Gash, J.H.C.; Nobre, C.A.; Roberts, J.M.; et al. (Ed.). Amazonian Deforestation and Climate, Wiley, Chichester, p.151-162.

USGS. 2004. Shuttle Radar Topography Mission, 1 Arc Second scene SRTM_u03_n008e004, Unfilled Unfinished 2.0. Global Land Cover Facility, University of Maryland, College Park, Maryland, February 2000.

Vieira, R.M.S.P.; Alvalá, R.C.S.; Cunha, A.P.M.A.; Sestini, M.F.; Carvalho, V.C.; Valeriano, D.M.; et al. 2013. Mapa de uso e cobertura da terra do território brasileiro para uso em modelagem climática e meteorológica. INPE, pp.42. (http://urlib. net/8JMKD3MGP7W/3ECULQ5). Accessed on 15 June 2014.

Von Randow, R.C.; Siqueira Júnior, J.L.; Rodriguez, D.A.; Tomasella, J. 2012. Modeling the hydrological effects of secondary forest growth in abandoned deforested areas in Amazonia. In: $A G U$ Fall Meeting San Francisco, San Francisco.

Wigmosta, M.S.; Nijssen, B.; Storck, P.; Lettenmaier, D.P. 2002. The Distributed Hydrology Soil Vegetation Model. In: Singh, V.P., Frevert, D.K. (Ed.). Mathematical Models of Small Watershed Hydrology and Applications. Water Resource Publications, Littleton, p.7-42.

Xue, Y.; Sellers, P.; Kinter, J.; Shukla, J. 1991. A simplified biosphere model for global climate studies. Journal of Climate, 4: 345-364.

Received: 04/08/2016

Accepted: 14/06/2017 
